\title{
The Paradox of Tethering: Key to Unleashing Creative Excellence in the Research-Education Space*
}

\author{
David J. Waters, PhD, DVM \\ Professor of Veterinary Clinical Sciences \\ and Associate Director, Purdue University \\ Center on Aging and the Life Course; \\ Director, Center for Exceptional Longevity Studies, \\ Gerald P. Murphy Cancer Foundation, West Lafayette, IN, USA
}

\section{waters@purdue.edu}

\begin{abstract}
*A paper delivered as a keynote address at the International Symposium on Interdisciplinary Research, Education and Communication (IDREC), $3^{\text {rd }}$ Informatics and Cybernetics (IMCIC) on March 26, 2012 in Orlando, Florida.
\end{abstract}

\begin{abstract}
Creative excellence in interdisciplinary research, education, and communication demands stamina and openmindedness. Stamina requires renewal, yet few opportunities for self-renewal are built into most systems. And as experts, our openmindedness is often stifled by our own sense of finishedness. This paper sketches out a strategy for sustained renewal and creative excellence: Each person assembling a gallery of hand-picked intellectual heroes to serve as their life-long teachers. It argues that tethering ourselves to intellectual heroes does not limit our creative potential but instead achieves exactly the opposite effect - enabling us to see and reach our own greatest potentialities. By strengthening the habit of strategic tethering, we situate an active, partially guided search for self-renewal and a heightened receptivity to new ideas at the very core of achieving excellence in the research-education space.
\end{abstract}

Keywords: interdisciplinary, science education, peak performance, metacognition, perception, dialogic self-awareness, poet-scientist, framing, psycholinguistics, self-renewal.

\section{Introduction}

I'm trained as an expert in the comparative aspects of cancer and aging in pets and people. That means I'm primed for seeing and reporting similarities and differences. For example, my re-

Material published as part of this publication, either on-line or in print, is copyrighted by the Informing Science Institute. Permission to make digital or paper copy of part or all of these works for personal or classroom use is granted without fee provided that the copies are not made or distributed for profit or commercial advantage AND that copies 1) bear this notice in full and 2) give the full citation on the first page. It is permissible to abstract these works so long as credit is given. To copy in all other cases or to republish or to post on a server or to redistribute to lists requires specific permission and payment of a fee. Contact Publisher@InformingScience.org to request redistribution permission. search has shown that dogs and men are the only two species in which prostate cancer naturally occurs with appreciable frequency (Waters \& Wildasin, 2006). I am also very interested in the science of successful aging. To unlock the secrets of highly successful aging, some scientists study people who live to be 100, so-called centenarians (Figure 1). The subjects I study don't wear big, floppy hats. Instead, my research team 


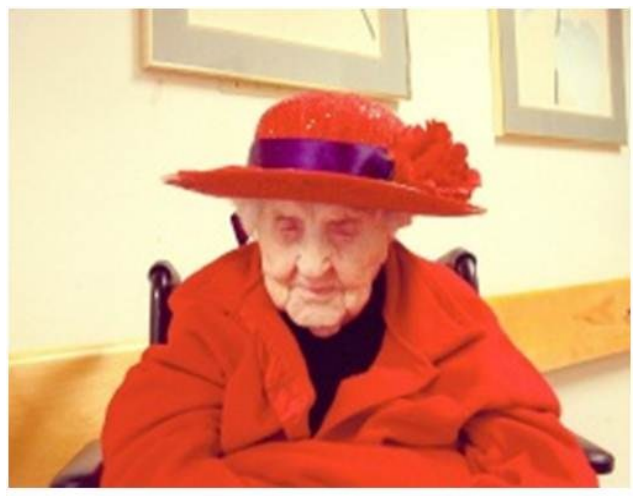

Figure 1: Photograph of Neva Morris, age 114 years. Centenarians provide a unique opportunity to discover the biological underpinnings of highly successful aging. Image source: Ames Historical Society, used with permission. is testing a new idea - that the secrets to successful aging can be revealed by studying exceptionally long-lived pet dogs (Waters, 2011). At the Center for Exceptional Longevity Studies we have established the Exceptional Longevity Data Base, the first systematic study of the oldest-living dogs in the United States as models of human aging. In 2010, I embarked on a first-of-its-kind scientific expedition: The Old Grey Muzzle Tour. During a 22-day crosscountry trek, I visited 15 of the oldest-living dogs in the United States in their homes to make first-hand observations, conduct physical examinations, and collect biological samples. I could relate to you some pretty amazing stories about canine centenarians, but on my mind today is the idea of creative excellence and sharing my experience from teaching a graduate level "skills course" in Purdue Uni-

versity's Center on Aging and the Life Course. The course probes the skills and attitudes that foster creative excellence and promote peak personal performance. Students in the course come from a broad array of disciplines, such as sociology, immunology, nutrition, and kinesiology. Our efforts in this educational encounter are authentically interdisciplinary - we are searching for factors that spur creative excellence and transcend discipline.

When you think of creative excellence, what words come to mind? Words like "trailblazing", "uninhibited", or "original" are among the usual suspects (Figure 2). One word that is not typically associated with creative excellence is tethered - the condition of being tied to something. But today I will propose that the right kind of tethering is an essential part of creative excellence and reaching your highest potential. This line of thinking is captured in the title of my keynote address: "The Paradox of Tethering: Key to Unleashing Creative Excellence in the Research-Education Space." Webster defines paradox as a person, situation, or act that seems to have contradictory or inconsistent qualities. Two questions will help us calibrate the paradoxical potential of my thesis. Should tethering stifle creativity? Or does tethering actually stimulate creativity? Stifle or stimulate? I contend that tethering oneself to intellectual heroes does not

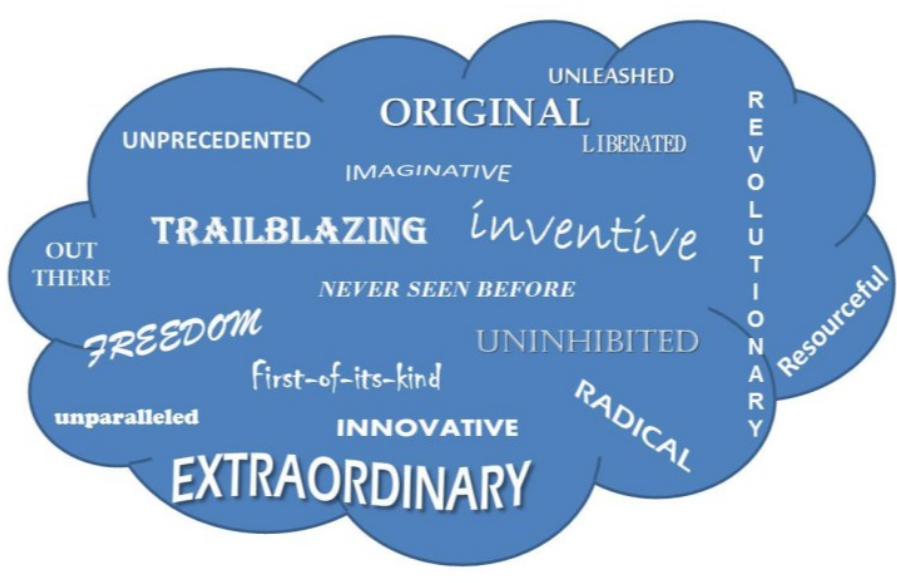

Figure 2: Words that are typically used to describe creative people and their ideas. limit one's creative potential but instead achieves exactly the opposite effect - enabling one to see and reach their own greatest potentialities. In 2011 , I published a paper entitled "On the Self-Renewal of Teachers" that laid out a strategy for sustained renewal and creative excellence: Each person assembling a gallery of hand-picked intellectual heroes to serve as their life-long teachers (Waters \& Waters, 2011). Today, I see it as a call for action against a troublesome tide. A disturbing testimony to 
our distracted lives is that most of us can readily name our favorite film actors or sports stars, but we would be found wanting if asked to compose a roster of our intellectual heroes, those thinkers who inspire us. We need intellectual heroes. Heroes reveal to us something about our inner selves, helping us "to learn the deepest secret of our capacity" (Whicher, 1953). As we prepare to leap into performance, intellectual heroes show us just how high we can set the bar.

In this paper, I will share some ideas - many of them inspired by my own intellectual heroes about how to achieve creative excellence in a research-education space. My hope is that some of the ideas will resonate with you, challenging your current ways of thinking, presenting new possibilities to you and your students, opening new opportunities for personal growth and performance. My intent is to provide a thoughtful perspective on the field of creative performance while avoiding any sort of encyclopedic urge for completeness. Instead, my intent is to frame some instructive segments, then drive my conclusion toward what I hope will be a satisfying synthesis.

\section{On The Quality of Your Reading}

We don't spend enough time thinking about the quality of our reading - the way we interact with text. Picture yourself sitting in your favorite chair, reading a gripping novel. The story grips you because it holds just the right amount of details and gaps. When the young lady in the story asks the gentleman what time it is, you fill in the blank as to what his timepiece looks like. You do it all the time - this interaction between you and the text. Every text has gaps waiting to be filled. Reading, then, is an act of filling. What we need to avoid is failure in our reading. Failure in reading, wrote Wolfgang Iser, occurs when all the gaps get filled in with your own preconceptions - with what you believed before you picked up the text (Iser, 1978). Success is only achieved when you are willing to fill the gaps with new ways of seeing stimulated by the text.

Consider this example. When we read a news article about health, many of us consider what we read as truth without questioning its merit. And if the findings fit our preconceived notions, we accept them immediately. For example, you read a report that says obesity is a major problem associated with an increased risk for diabetes and heart attack. This likely fits the view you held before you picked up the article. Therefore, any gaps between you and the text are obligingly filled in by you with your long-held views. You ask no hard questions. There's no chance for change. But is this notion of obesity as "bad" really universally correct? Could it be that at a certain age, say 70 years, being a little fatter means that when you fall you bounce and roll rather than break a bone? In other words, is there eventually an age at which there's a positive payoff for being chubby? To understand anything more deeply - even bouncing and rolling - we must ask questions. It's all about the quality of our questions. We need to grow to recognize reading as an intense transaction, not a passive one-way oozing of information from text to reader (Rosenblatt, 1978). We must come to crave the collision of ideas that will provoke both destruction and synthesis - our own productive dismantling and re-assembly.

If we can learn to see reading as a valuable opportunity for self-observation (Richards, 1942), then curling up with a text becomes the healthiest of exercise for the reader who will go farthest to examine his own possibilities. And if our goal is personal growth, is it more productive to read one book, put it down, then read another, put that down, then read another? Or would it be better if we limited our efforts to reading one book followed by re-reading that book? To expand our horizons, it would seem logical that the first scenario might be the superior choice. But literary critic Roland Barthes would respectfully disagree. Instead he would challenge us to reorient our thinking. To Barthes, the best reading necessitates re-reading. "Those who fail to re-read are obliged to read the same story everywhere", wrote Barthes (1974). What we see in the text the first time is largely ourselves, our preconceptions and biases. It is only through re-reading that we dig deeper, enabling the brain-text transaction to penetrate us and re-shape our ways of 
thinking so that we might see and believe anew. That the most rewarding reading is re-reading is also the notion sported by Mortimer Adler in his classic How to Read a Book (1940), a book I strongly recommend to students who are looking to transform the way they read, their encounters with text. It follows then that we should insist that our young trainees frequently engage in re-reading.

Reading is more than just an intellectual exchange. Thoreau reminds us that the best reading precipitates action. "A truly good book teaches me better than to read it. I must soon lay it down and commence on its hint ... What I began by reading, I must finish by acting," wrote Thoreau (Torrey, 1906). I like this idea of the reader provoked to act, rather than stuck in some sedentary state. The coveted endpoint of reading is purposeful action.

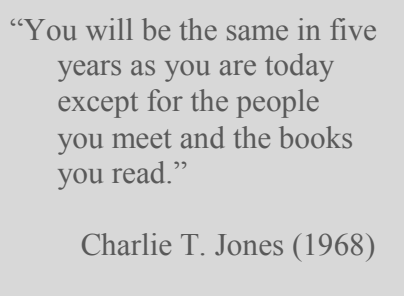

'You will be the same in five years as you are today except for the people you meet and the books

But I must admit that sometimes I pick up a text with a very different motive in mind. So before leaving the topic of reading, I offer up an even more radical challenge to the reader, imploring him, should he decide to, to go far beyond the intent of the writer. Sometimes I engage in a premeditated mode of reading - what I term reading for pure provocation - in which I am looking to hijack a phrase, or find a single word that will fuel my tantrum, an exploding of thought about whatever is preoccupying my attention. This sort of reading guarantees fireworks for the reader who has readied himself and is committed to the leap, primed for discovering a new angle to view his problem, a fresh description of self. We have come to know the world by listening to collections of words - partly informative, partly suasive - that have shaped and re-shaped our beliefs. Sometimes, to fuel our imaginations, we should break away from pure information-seeking and pursue pure provocation. We accomplish this by broadening our encounter with words, especially those used in new and unexpected ways.

\section{On The Quality of Your Writing}

If our goal is to master textuality (Scholes, 1998), we must not only grow our skills of reading but rev up our repertoire of writing skills. Although I will limit my comments here to writing, I believe those in pursuit of creative excellence should feed an even bigger ambition - coming to recognize great value in going beyond reading and writing to master the art of discourse, which combines the skills of reading and writing, listening and speaking. James Moffett's terrific book Teaching the Universe of Discourse (1983) will become a valued guide for those who resolve to explore more deeply a larger universe of discourse.

I credit Donald Murray, Pulitzer prize-winning writer, for recasting my view of writing. His book, The Craft of Revision (1991), exposed me to many pearls that had previously dodged my attention. To Murray, all writing is re-writing. We need to see writing as a process, one that requires great courage. We are not writing our best when we limit ourselves to recording our thoughts. Only when we have the courage to write things we have never reasoned through before do we employ the writing process as a tool to generate new thinking, rather than reducing writing to the mere act of recording. Murray (1991) describes convincingly the power of what he calls "the discovery draft". Using this method, the writer rapidly deposits on paper his draft, a rushing flow of ideas, without worrying too much about sentence structure, punctuation, or even the organization of his thoughts. The payoff comes when the writer carefully probes the discovery draft to pin-point that kernel of thought from which he will totally re-write his piece. If expanding your writing skills is your goal, you can't go wrong tethering yourself to Murray.

As my students and I have focused on the skills and attitudes of creative excellence, my appreciation for the close linkage between good writing and clear thinking has grown. Two texts by William Zinsser, On Writing Well (1980) and Writing to Learn (1988), reinforce the often overlooked 
association between the quality of our writing and the quality of our thinking. If you cannot write a clear description of how to a fly a kite, smart money says you possess a muddled understanding of how to fly kites. So the payoff for improving your writing skills is an "internal eloquence", a clearer internal dialogue that shapes and re-shapes your understandings and beliefs, and ultimately the way you frame your ideas.

If you are eager to expand your repertoire of written communication skills, perhaps mastery of the classic style of prose should be on your to-do list (Thomas \& Turner, 1994). Classic style prose is a disciplined mode of communication - an art of framing the essential that comes from a selfdisciplined attitude of detachment and objectivity, so it gives a strong impression of reliability. On surface examination, it appears very clear and simple. But the impression of spontaneity that the classic style produces is a fictive impression behind which are the author's deeply prepared, mature thoughts. As the author of classic style prose, you are delivering a performance whose preparation is hidden, whose sense of spontaneous perfection can be perceived by the reader immediately, without deeper re-examination. Your message seems axiomatic, a simple truth undistorted by the ambition of persuasion - the way that Thomas Jefferson wrote The Declaration of Independence. Thomas and Turner (1994) point out that the success of the classic style grows out of a carefully constructed symmetry between writer and reader so that the exchange is readily accessible to the reader, not contingent upon the reader having any specialized, out-of-theordinary expertise. It is as if a receiver, after encountering a writer's account, would remark: "You know if I had walked in the shoes of this writer, I would have made the same observations she did, and asked a new set of questions like she did, and would have come to believe the way she does now." The more familiar you become with this style of discourse, the more clearly you will see that a writer mastering the art of classic prose is surely engaged in an enviable high performance, high wire act.

\section{On How We Tackle Tough Questions}

As we consider what factors might separate average performers from peak performers, it would make sense that some attention be directed at how we handle tougher questions. In his recent book, Thinking, Fast and Slow (2011), Princeton's Daniel Kahneman reminds us that our personal performance hinges on the ability to identify and understand errors of judgment and choice. In his research, Kahneman has emphasized the need to develop a richer and more precise vocabulary for how we think and how we describe the thinking mind. Reading his book brought me face-to-face with a question of import I had never confronted before: How does a brain trained to think fast answer difficult questions? Kahneman's revealing reply: Faced with a difficult question, your brain quickly diverts itself to other related questions that it can answer more quickly. Often we answer an easier question that we have substituted, without even noticing our act of substitution. Incredible. Kahneman's insight has moved me to wonder about the attitude we refer to as "openmindedness". How often do we engage a new idea with an "openmindedness" that produces nothing more than a product of fast brain substitution? And I wonder just how often do we productively engage new ideas with brute openmindedness - the kind of genuine, mental wrestling with the difficult and unfamiliar that actually positions us to change our beliefs? Each of us needs to develop a richer mental picture of what it means to be openminded. There is such a strong tendency for experts to get close-minded and stuck in the ruts of expertise, no longer open to fresh seeing, fresh believing. Successful self-renewal, in part, is rut-proofing yourself and celebrating your unfinishedness, rather than prancing forward smug in your expertise. 


\section{On What Is a Scientific Manuscript}

In science, we are accustomed to benchmarking progress in particular domains by our peerreviewed published manuscripts. But what exactly is a scientific manuscript? And is there such a thing as the definitive study? The literary critic I. A. Richards once commented that when you listen to the people who speak the loudest, it seems as if they have seen everything, when in reality, what they have is "a view formed under special circumstances" (Richards, 1976). Like the words that escape the mouths of Richards' roaring few, doesn't the moniker "a view formed under special circumstances" precisely describe every scientific manuscript? In 2009, we published our data from dogs on the relationship between keeping ovaries longer and living longer (Waters et al., 2009). The paper was entitled "Exploring Mechanisms of Sex Differences in Longevity: Lifetime Ovary Exposure and Exceptional Longevity in Dogs". It could have just as easily been entitled "A View Formed Under Special Circumstances". In 2010, my research group published data on the relationship between the trace mineral selenium and prostate cancer prevention (Chiang et al., 2011). This paper carried the scholarly title "Defining the Optimal Selenium Dose for Prostate Cancer Risk Reduction: Insights from the U-Shaped Relationship Between Selenium Status, DNA Damage, and Apoptosis". We could have called it "A View Formed Under Special Circumstances" (Figure 3). A recent paper published by Ristow and colleagues in the prestigious Proceedings of the National Academies of Sciences reported that exercise improves blood sugar regulation in people, but the combination of antioxidants and

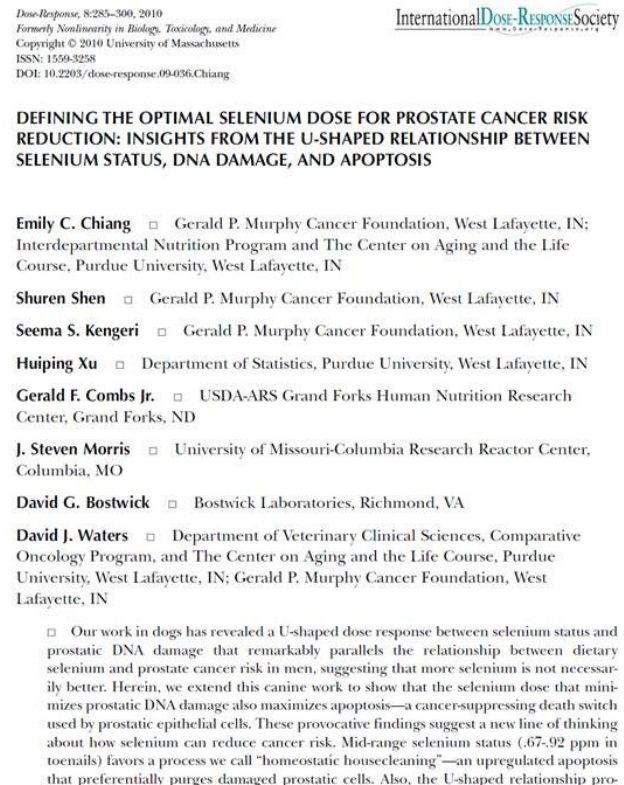

InternationalDose-ResponstEociety

DEFINING THE OPTIMAL SELENIUM DOSE FOR PROSTATE CANCER RISK REDUCTION: INSIGHTS FROM THE U-SHAPED RELATIONSHIP BETWEEN SELENIUM STATUS, DNA DAMAGE, AND APOPTOSIS

Emily C. Chiang $\square$ Gerald P. Murphy Cancer Foundation, West Lafayette, IN Interdepartmental Nutrition Program and The Center on Aging and the Life

Course, Purdue University, West Lafayette, IN

Shuren Shen $\quad$ Gerald P. Murphy Cancer Foundation, West Lafayette, IN

Seema S. Kengeri $\square$ Gerald P. Murphy Cancer Foundation, West Lafayette, IN

Huiping Xu Department of Statistics, Purdue University, West Lafayette, IN

Gerald F. Combs Jr. $\square$ USDA-ARS Grand Forks Human Nutrition Research

Center, Grand Forks, ND

J. Steven Morris $\square$ University of Missouri-Columbia Research Reactor Center. Columbia, MO

David G. Bostwick $\square$ Bostwick Laboratories, Richmond, VA

David J. Waters $\square$ Department of Veterinary Clinical Sciences, Comparative

Oncology Program, and The Center on Aging and the Life Course, Purdue

University, West Lafayette, IN; Gerald P. Murphy Cancer Foundation, West

Lafayette, IN

- Our work in dogs has revealed a U-shaped dose response between selenium status and prostatic DNA damage that remarkably parallels the relationship between dietar ily better. Herein, we extend this canine work to show that the sectenimm dose that mint mizes prostatic DNA damage al co maximizes apoptosis-a Cancer-suppressing death switch used by prostatic epithelial cells. These provocative findings suggest a new line of thinking about how selenium can reduce cancer risk. Mid-range selenium status $(.67 .92 \mathrm{ppm}$ in toenais)

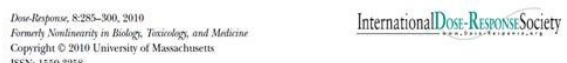

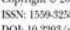

A VIEW FORMED UNDER SPECIAL CIRCUMSTANCES

Emily C. Chiang $\square$ Gerald P. Murphy Cancer Foundation, West Lafavette, IN Interdepartmental Nutrition Program and The Center on Aging and the Life Course, Purduc University, West Lafayette, IN

Shuren Shen Gerald P. Murphy Cancer Foundation, West Lafayette, IN

Seema S. Kengeri $\square$ Gerald P. Murphy Cancer Foundation, West Lafavette, IN

Huiping $X_{u} \quad$ Department of Statistics, Purdue University, West Lafayette, IN

Gerald F. Combs Jr. ㅁ USDA-ARS Grand Forks Human Nutrition Research

Center, Grand Forks, ND

J. Steven Morris University of Missouri-Columbia Research Reactor Center Columbia, MO

David G. Bostwick ㅁ Bostwick Laboratories, Richmond, VA

David J. Waters $\square$ Department of Veterinary Clinical Sciences, Comparative Oncology Program, and The Center on Aging and the Life Course, Purdue University, West Lafayette, IN; Gerald P. Murphy Cancer Foundation, Wes Lafayette, IN

Our work in dogs has revealed a U shaped dose response between selenium status an prostatic DNA damage that remarkably parallels the relationship between dietar ilv better. Herein, we extend this canine work to show that the selenium dose that minit used by prostatic epithelial cells. These prosocative findings suggest a new line of thinking about how selenum can reduce cancer risk. Mix-range selenium satus $(.67 .92 \mathrm{ppm}$.

Figure 3: What exactly is a scientific manuscript? Shown here is the title page of a manuscript with actual title (left panel) and a hypothetical title page of the same manuscript showing a substituted title (right panel). Because no investigator possesses a privileged view of Truth, all of us gain valuable perspective when we remind ourselves that every scientific manuscript ever written could be quite accurately entitled "A View Formed Under Special Circumstances". Image source: Dose-Response, used with permission. 
exercise has no effect - supplementation with dietary antioxidants seems to block the beneficial effects of exercise on blood glucose control (Ristow et al., 2009). The paper was entitled "Antioxidants Prevent Health-Promoting Effects of Physical Exercise in Humans." It could have been published as "A View Formed Under Special Circumstances." Why not? The investigators decided who would be the study subjects, and they chose the intensity of exercise and the dose of antioxidant supplements, even the parameters used to describe the degree of blood sugar control. Like all investigators, they chose the special circumstances that came to be known as their experiment. And they faithfully reported their results. Picasso (1923) said, "Art is a lie that lets us recognize the truth." I say that my manuscript (your manuscript too!) is a lie that lets us recognize the truth. A scientific manuscript is just one more step in a process, a cobblestone in the path toward a deeper understanding. If we as scientists, clinicians, and the public would come to accept this, we would not be paralyzed by our lack of knowing, waiting for that definitive study that will allow us to act. There is no such thing as the definitive study. Jacob Bronowski (1978) wrote that no scientist should believe that your manuscript is Truth, with a capital T. That is because nobody can do the God's view experiment that includes all of the variables. Nature escapes our grasp because there is no privileged view. I believe we can better position ourselves for creative excellence if we grow to realize that each of our views - each of our experiences - is merely a view formed under special circumstances.

\section{On Process and Paradox}

A philosophy of process means that change is an essential part of reality's flow (Whitehead, 1966). Our best ideas are always incomplete, work in progress. The challenge then is to celebrate our belief, our progress in the moment, amidst reality's ambiguous and paradoxical flux.

Every scientist must come to realize that his brilliant new idea that he celebrates today will someday be thrown on the scrapheap of wornout ideas. But lying there discarded, will your idea be recognized for its beauty, its value as a stepping stone to a richer understanding? The answer to this question will be a resounding "yes" if the idea has moved others to ask and then answer a new set of questions. Progress, then, is judged not by our answers - our "facts" - but instead by the quality of the questions we ask. All progress is rooted in change. Young scientists, with their experiments and their imaginings, must

"The truth of an idea is not a stagnant property inherent in it. Truth happens to an idea ... its verity is in fact ... a process."

William James (1907) see themselves as agents of change. For progress to occur, sooner or later every scientist's big idea - the one that he holds now with so much conviction - will ultimately find its way to the dump.

As we navigate the day-to-day flux of our lives, we often find ourselves in situations of difficulty. When this happens, our inclination is to seek out and solve an underlying problem. But the flux of our experience is rich with paradox. The physicist-philosopher David Bohm (1996a) urges us to learn to discipline ourselves to avoid confusing what are paradoxes and what are problems. The most fruitful approach to paradox is one of acceptance and strategic navigation amidst competing forces, rather than a push to make the paradox go away through problem solving. By taking this more enlightened approach, we free our mind's problem-solving machinery for productive inquiry, rather than getting caught up in fruitless acts of iterative misfiring. To me, creative excellence grows out of brute attention to paradox. To enhance performance, I counsel my students to beef up their "sfumato" (Italian for "up in smoke"), the term Michael Gelb (1998) uses to describe the ability to thrive amidst uncertainty, ambiguity, and paradox. Do you know your comfort level with uncertainty and paradox?

Perhaps the secret to strengthening our capacity for creative excellence hinges on developing the right habits. In his masterpiece Principles of Psychology, William James (1890) devoted consid- 
erable attention to the study of "habit". Habits are the grooved paths that we etch into our neural circuits. These familiar paths are performance-enabling through their effects on efficiency and minimizing effort. We underestimate, says James, the power and pay-off of automaticity. I must agree. Habit moves us to act. So we should encourage our young trainees to put to habit as many useful things as possible that will lead toward ideals of outcome - habits such as the strategic tethering to intellectual heroes. But the goal of automaticity should not be confused with living a mechanical life. In fact it can lead to precisely the opposite outcome. Here we experience what I refer to as "the paradox of automaticity". Automaticity creates cognitive room - the space necessary for you to exercise your intellectual powers. Building your self-awareness through strategic automaticity catapults you away from a mechanical survival mode and gives you the freedom to work toward your highest possibilities. Your automaticity endows you with nothing less than a greater capacity for investing yourself in creative acts.

\section{On Becoming a Necessary Angel}

My students are committed to developing the skills and attitudes they will need as they dedicate themselves to a life of seeing and reporting as discoverer-teachers. So, in my skills course, I expose students to the poetic philosophy of Wallace Stevens, the Hartford insurance executive who was one of the most revered American poets of the $20^{\text {th }}$ century (Pack, 1968). Stevens reveals in his poems a versatile mode of thinking that challenges us to not accept surface impressions, but instead urges us to keep scratching, shaping our own local production of reality. His is a process philosophy that demands deeper inquiry and places high value on the skills of seeing and reporting our encounters with the world. In his poem, "Angel Surrounded by Paysans", Stevens proclaims: "Yet I am the necessary angel of the earth, /Since, in my sight, you see the earth again" (italics mine; Stevens, 1964). By dedicating your life to discovery within a particular region of search, you grow to see differently, you see farther than others. Then, by sharing your insights, others encounter ideas they would otherwise never have been exposed to. I see in Stevens' words the discoverer-teacher personified, heeding the calling of seeing and reporting. I call out to my students: Are you a necessary angel?

Is it sound thinking to situate a poet like Stevens at the heart of educational excellence and selfrenewal across a broad range of research disciplines? I believe so. In his poem "Of Modern Poetry", Stevens wrote, "The poem of the mind in the act of finding/ What will suffice" (Stevens, 1964). Truth with a capital T is beyond our grasp. Wallace Stevens' poetry - sometimes referred to as a poetry of failure (Crichley, 2005) - becomes a sobering yet guiding light for scientists, those who would courageously venture and adventure in pursuit of what will suffice. There is a paradox, so eloquently conveyed in Galileo's Fable of Sound (1623), that as the intensity and closeness of our study of a thing increases, the less sure we are of reporting what we actually "know" about that thing. If Galileo were to trot out his stance it would sound something like this: It is because I have looked so closely at comets that I have so few facts to say about them. We need to challenge our trainees' perception of what it means to be an expert, what it means to have a deep understanding. When we say we have a deep understanding, is it possible - in fact even probable - that we have only begun to scratch the surface? Wallace Stevens beckons us to keep scratching. His philosophy of process echoes Whitehead and Emerson. "Under every deep a lower deep opens", wrote Emerson (1847). Keep scratching. In most instances even our deepest thoughts are merely surface impressions, not glimpses of the thing itself. Even as experts, we must be prepared to deepen our stories and see the difficulties we encounter as the expression of a deeper design.

I've used Stevens' examination into what will suffice to coax my students to grapple with one such deeper line of inquiry: Should the goal of scientific research be a relentless search to find Truth or a perseverance to reveal Usefulness? If our goal is Truth, we are in the business of 
constructing theories. And as the thing we are attempting to understand becomes more complex, the theories we develop to discover Truth will become more and more complex, making it almost impossible to communicate their method or their yield. In contrast, if we set Usefulness as our goal, we arm ourselves with conceptual schemes - propositions that are not seeking to be allinclusive descriptions of a beyond-our-grasp Truth (Gill, 2011). We focus on forging tools that can hammer out meaningful progress - revealing relationships that are useful to us in some important way.

In his comparative analysis of Usefulness vs. Truth-seeking, Gill (2011) points out the importance of landscape ruggedness as a factor that investigators should consider before setting the goal of their research as Truth or Usefulness. Ruggedness mirrors the complexity of the system under study. If the landscape is smooth like rolling sand dunes, a discoverer-practitioner is more apt to set out on a journey to find a better place, a higher fitness, a more predictive vantage point. But as the landscape complexifies - acquiring the ruggedness reminiscent of Bryce Canyon's hoodoos - even a tiny step can move the discoverer-practitioner to a much less desired place. So in rugged landscapes, where theories are doomed to fall far short of describing reality, individuals are much less likely to venture out. And they are disinclined to ask questions. Instead, more advantage is found in observing the situations of others, rather than gathering new first-hand experiences of the world. Courageous trailblazing gives way to mimicry. Under the most severe of circumstances, discovery grinds to a halt.

Stevens' necessary angel will never stop discovering - discovering what will suffice. From the earliest days of their training, young people in science see themselves as being in pursuit of the Truth. But the purpose of biomedical research and medical practice is action, not perfection (Maurois, 1968). Forming beliefs based upon incomplete understanding is critical to taking the all-important action that avoids decision paralysis. In the minds of our young trainees, we need to temper the relentless search for Truth with a healthier respect for Usefulness, for what will suffice.

\section{On Becoming Hyphenated}

As researchers, we try to make sense of the world. Over the past two decades, investigators have come to recognize the strength of conducting this sense-making in an interdisciplinary way. The mantra for my research group has become "Ignore your mother. Play in the intersection." (Figure 4) We expand our chances of creative discovery by daring to operate in the underexplored intersections of domains, not sheltered within any particular silo. My colleagues and I believe, for example, that future breakthroughs in the field of cancer prevention will come from

\section{Ignore Your Mother ... Play in the Intersection}

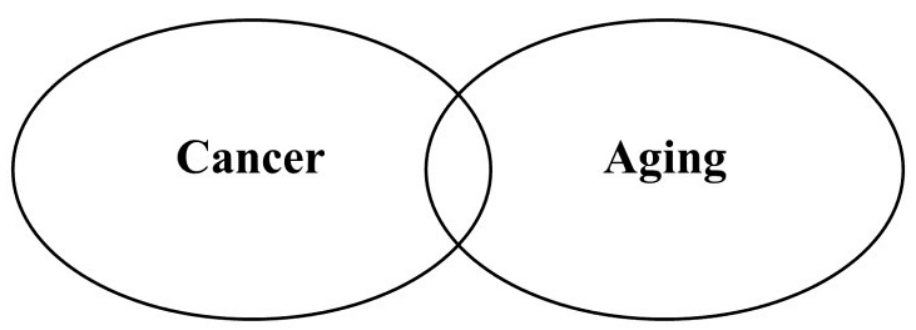

Figure 4: Serious discoverers see great value in positioning themselves for intersectional play in two or more domains. 
investigators who are cross-trained in both cancer and aging science, since most cancers develop in old tissues (Waters, Chiang, \& Bostwick, 2008). Old tissues provide the context for the cancer development process. And context matters. Unfortunately, few cancer scientists are cross-trained in the biology of aging.

Yes, context matters. But as discoverers, are we sufficiently schooled in the importance of context? The anthropologist-systems thinker Gregory Bateson (1979) singled out the historianphilosopher R.G. Collingwood as one of his intellectual heroes, noting that no one possessed a surer grasp of context than Collingwood. In 1924, Collingwood published Speculum Mentis: The Map of Knowledge, an ambitious attempt to resolve the immensity of Nature (Figure 5). Immediately obvious in the text is that Collingwood sees clearly the difficulty in making sense of the world. He puts forth the question: Who will give us the truest view of the world - the artist, historian, philosopher, scientist, or theologian? He quickly finds the solution to his big question will

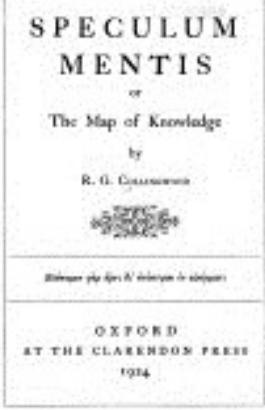

Figure 5: In Speculum Mentis, R.G. Collingwood asserts that the truest description of Nature is a progressively determined process contributed to by every genuine thinker. not come easily because, when asked, the artist will offer, "We see the world best through aesthetics, beauty"; the scientist will say, "We see best when we apply the scientific method", and so on. Collingwood's sobering conclusion: We can't trust any of them. And that's when it hit me - It pays to be hyphenated. Historian-Theologians, Artist-Philosophers, and other hyphenated types are in the best position to side-step some of the limitations inherent in a single-minded approach to discovering. My personal bias: We need more Poet-Scientists - scientific discoverers who care deeply about language. It will be through their thinking and writings that we will come to recognize more fully how the act of naming things limits the scientific method, so that a truer reality can be revealed. Emerson (1893) wrote: "What is life but the angle of vision." Collingwood's idea echoes Emerson's thinking, encouraging each of us to value the expertise of the multi-angled among us. If our goal is discovering the whole, it will pay to become hyphenated. Are you hyphenated yet?

\section{On The Importance of Language and Developing Dialogic Self-Awareness}

Many of our performance ruts are precipitated by our imprecise use of language. As we seek to make sense of the world, we are prone to making meaningless reductions by our use of either-or. Either-or-ness - reducing people to smart or dumb, thinking that a dietary supplement is either good or bad, seeing a venture as successful or unsuccessful - gets us into trouble. We oversimplify the world and muddle information when we fall into the trap of either-or-ness. Eitheror-ness is at the root of oversimplified health messages (Waters \& Chiang, 2010). For example, the seemingly innocent question, "Is vitamin E good for me?", is a meaningless oversimplification because it ignores context. If we were more precise with our use of language, we would be moved to ask the better question, "Under what circumstances will vitamin E supplements benefit me?" The general semanticist Wendell Johnson $(1946 ; 1956)$ said we see the world through our categories. Either-or-ness, using two categories to describe the world, never suffices. Instead, the skilled imagination sees and reports a continuum of appearances. In the future, to optimize health we will need to embrace a more sophisticated way of seeing - seeing all choices, all interventions as both "good" and "bad". Applying this kind of whole-organism thinking along 
with a life-course perspective will provide the context needed to see and report the inevitable trade-offs that can antagonize or promote superior health outcomes.

Over the years, I have found it quite surprising how little time most discoverer-teachers spend attending to the ambiguity of language. Maybe it is because poets fiddle with the ambiguity of words, while law-abiding scientists make a concerted effort to squeeze out as much ambiguity as possible. More than any person who ever lived, I. A. Richards dedicated his life to the careful study of the ambiguity of our language and the art of close reading (Berthoff, 1985). In fact, Richards studied ambiguity so extensively that he coined a new, less derogatory term to describe his prized subject of study: the resourcefulness of words (Richards, 1942). In his book Speculative Instruments (1955), Richards pondered the implications of ambiguity on teaching and learning: "I don't know a subject in which study of the resourcefulness of its key terms doesn't amount to the subject, properly studied, itself." Last year, teaching graduate students at Purdue University, I set out to validate Richards' radical idea. I developed a new course on hormones and longevity entitled "Endocrinology of Aging". Instead of placing emphasis on the acquisition of facts within the subject domain, the students and I focused on the language used in the domain. We were particularly attentive to words whose meaning might not be immediately obvious to the student approaching the field of endocrinology for the first time. For example, students worked to understand in which ways the terms heterogeneity, complementarity, windows, and biomarkers were used by endocrinologists. The final oral exam focused on exploring the relations between a collection of 50 terms used in the field that we had constructed. I was gratified with the outcome of this premium-placed-on-language approach to scientific learning. In exit interviews, students reported that they enjoyed an extraordinary comfort level with the subject; the endocrinology of aging was no longer an opaque entity, instead they felt as if they had achieved a strong sense of accessibility to this scientific domain. The course came to be known as "Endo-Comm", as it proved to be a productive collision between endocrinology and communication. Reinforced in the students' minds was the notion of language as gateway to understanding and high performance. Not just for effective communication with others, but for becoming more effective in "talking" to themselves, shaping and re-shaping the ideas inside their heads.

I am beginning to see language as gateway to perfecting our intellect. Accordingly, a deep passion for precision with language rests at the core of what I call dialogic self-awareness the capacities that enable you to reach your greatest potential, to most effectively see and report your authentic experience with Nature. To me, strong dialogic self-awareness is the product of strengthening three language-anchored capacities: perceptual acumen, conceptual acumen, and the art of framing. We must develop perceptual acumen to grasp the truest picture, a near authentic representation of reality. To see clearly, we engage in the necessary act of abstracting attempting to accurately extract the most meaningful pieces of our experience, the differences that make a difference. Then comes conceptual acumen - the process of organization, the hard mental work of model building and reflecting upon the combinatorial abstractings of experience. The creative life is an infinite game of building then re-building our mental models. Reflection takes time and energy, but the payoff is great. It enlarges the past by revealing it open to further interpretation. The unfinishedness of the past, combined with your own unfinishedness in the present, makes possible for you to shape a bigger chunk of your future. But to untangle any external confusions, we cannot stop with those spiraling events taking place inside our heads - our perceptual acumen and conceptual acumen. We must transition into spoken language our winning insights, our glimpses of Nature's imagination. We must find language that will influence others who are wrestling indecisively with multiple interpretations. This is the art of framing. It too demands 
skill with language - recognizing and exploiting the ambiguity of words, their resourcefulness. The art of framing enables us to go beyond the information given - just the right distance beyond our facts. Our framing feeds the next question; it fuels the next level of inquiry. It successfully takes thinking beyond ourselves and effectively concentrates the attention of others.

\section{On Perception and Net Presentation}

Just how important is perception to performance? In his book The Creation of the Future, Cornell president Frank H. T. Rhodes (2001) wrote: "Our species is distinguished, not chiefly by its anatomy, but by its perception..." Rhodes thinks it is our perceptive powers that separate us from the pack. I agree. Consider the following text:

Aoccdrnig to rscheearch at an Elingsh uinervtisy, it deosn't mttaer in waht oredr the ltteers in a wrod are, olny that the frist and lsat ltteres are at the rghit pcleas. The rset can be a toatl mses and you can sitlll raed it wouthit a porbelm. Tihs is bcuseae we do not raed ervey lteter by ilstef, but the wrod as a wlohe. (Wind \& Crook, 2006)

Why is this mysterious text so surprisingly readable? It is because we deploy our powers of perception. Perception is a deliberate omitting of details in order to make sense of an experience (Dewey, 1958). In fact our capacity for producing order out of chaos is so powerful that as we process the last word of the scrambled text, "wlohe", our brains are ready to believe that we actually encountered "whole" in its properly spelled form. What we take away from each experience - what we see - is always a local production. I guess we could say reality is that part of reality that impresses us (Quinn, 1963); and likewise your data set is that part of your data set that impresses you. Ralph Waldo Emerson, a man of fewer words, put it this way: "Perception makes" (1983). When it rains, it is our perception (not the rain) that makes us mope or dance about.

Philosopher John Dewey teaches us that the subjectivity of experience has important implications for what we believe, and how creatively we respond to any given situation. By recognizing the process of perception as central to experience, man is emancipated - at his disposal he finds new powers of observation and experiment, new powers of shaping his emotional state, his desires, his questions that will assist him in his highest goal: to produce for himself an advantageous modification of those objects he encounters (Dewey, 1958). The work he is engaged in is an active shaping of Nature. To tap into Nature more deeply, he must develop a subjective mind - a mind that recognizes process as its special object of attention. He must fight against and triumph over his natural bias toward seeing things rather than seeing processes. Without perceptual skill and skill in thinking about his perceptions, he is at risk for living in a world unanalyzed. Each act of experience will always be a process of abstracting. The chair over there becomes a collection of sense data, plus a surrounding cluster of ideas. Not the chair complete, but details deliberately omitted. Creative excellence is fueled by your proclivity for plucking out those useful bits of subjectiveness from your primary experience with Nature. These bits serve as tools for constructing the ways in which experienced objects can be more advantageously managed. The quality of these constructions regulates the quality of your encounters, as these constructions confer your ability to regulate Nature or make useful predictions. These efforts also enrich your sense of meaning and value, enlarging your understanding by more fully recognizing relationships and relational differences. So much of interdisciplinary scientific discovery is the ability of subjecting old ideas - not original ones - to new relation and interpretation. It is mastering the art of attending to particulars and synthesizing new wholes.

Therefore, when it comes to developing our perceptual acumen, we must develop a keener awareness of what David Bohm (1996b) refers to as "net presentation", the idea that in any given encounter our experience is never pure sense data. We react to Nature filtered through us. Filtered through our previous thoughts, our presuppositions, and biased expectations encultured 
within us from our previous experience. Bohm teaches us that experience is net presentation, a mixture of presentations (sense data) and re-presentations (outside thoughts that pervade us). Next time you are writing up your exciting new research findings, remind yourself: Do not be satisfied with the surface impressions that fit the hypothesis that you treasure so dearly. If Wallace Stevens can write a poem "Thirteen Ways of Looking at a Blackbird", shouldn't you commit yourself to "Thirteen Ways of Looking at My Data Set"? Keep looking, keep scratching beneath the surface to see the plurality of each encounter. And through strengthening your dialogic self-awareness, you just might achieve the optimal blend of surface acceptance and skepticism, of independent first-hand experience and culturally-based belief.

"The greatest scientist knows but one tree of a mighty forest; he entertains an illusion when he thinks he can speak of the forest," wrote Andre Maurois (1968). I would be even less optimistic than Maurois about what the scientist actually "knows". I would say the scientist knows not one tree, but the image of one tree from a limited perspective, a view formed under special circumstances.

\section{Synthesis}

Creative excellence in interdisciplinary research and education demands stamina and openmindedness. Stamina requires renewal, yet few opportunities for self-renewal are built into most systems (Fox, 2000; Gardner, 1963). And as experts, our openmindedness is often stifled by our own sense of finishedness. In this paper, I have tried to emphasize that creative excellence can be achieved by recognizing our own unfinishedness and then tethering ourselves to intellectual heroes who become our life-long teachers. By constructing your own gallery of intellectual heroes, you are provoked to new angles of vision, new heights of possibility. Is this a new idea? Not really. More than forty years ago, the literary critic and biographer Walter Jackson Bate wrote: "We need not be passive victims of what we call circumstances ..., but that by linking ourselves ... with the great we can become freer - freer to be ourselves, to be what we most want and value" (Edmundson, 2004. p. 92). Clearly, Bate was lobbying in favor of strategic tethering. More recently, Michel Ferrari (2002) has written that seeking out narratives about exceptional individuals lures us into our culture's noetic space - a world of imagined possibilities whose boundaries are expanded to hold the full range of imaginings by individuals as they confront the circumstances into which they are thrust. Here, I have argued that tethering ourselves to intellectual heroes does not limit one's creative potential, but instead enables us to see and reach our own greatest potentialities. By strengthening the habit of strategic tethering, each of us can situate an active, partially guided search for self-renewal and a heightened receptivity to new ideas at the heart of achieving excellence in the research-education space.

As humans, we must feed not only our natural instinct to move - our mobility addiction - but also our instinct to emulate, to copy and become more like what we see. That is why the idea of developing your own gallery of intellectual heroes - life-long teachers like Kahneman and Bohm, Collingwood and Stevens - is so appealing (Figure 6). Using the tethering to heroes as a technique to boost creativity may sound a bit paradoxical, counterintuitive. But heroes extend us. They inspire. Heroes teach ATTENTION. Heroes teach PROCESS. Heroes teach ELOQUENCE.

Moreover, our intellectual heroes show us that it pays to be hyphenated. In this paper, I set out to spotlight the rationale for developing more poet-scientists. The motive behind moving scientists to become hyphenated is not to destroy their confidence in the scientific method. It is to call their attention more truly to the limitations of the method they revere - a loosening-up of the singleminded view of discovery the scientist holds so tightly. Earlier, I stated that as researchers we try to make sense of the world. What I should have stated is that all of us - from die-hard researchers to John Q. Citizen - are attempting to make sense of a world of words. That is why by sharpening his poetic self - by caring more deeply about language and seeing - the discoverer will 
come to see his act of naming, the experimental design he imposes, as limiting what he can grasp from his momentary glimpses of Nature, his experience. The fully prepared poet-scientist will emerge more sensitive, more circumspect — ready to see and report his own version of the suggestions of Nature, his version of what will suffice.

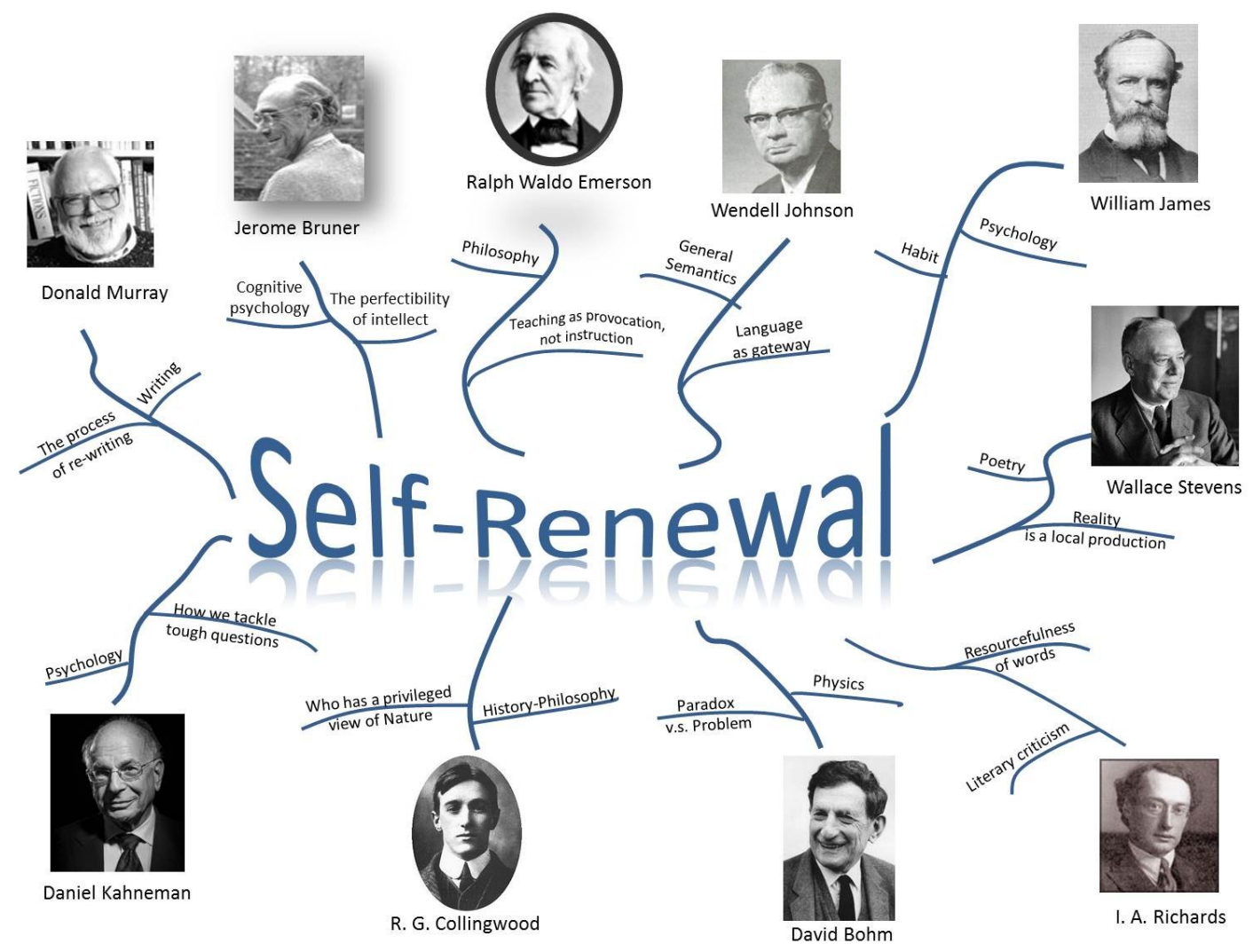

Figure 6: Ten Intellectual Heroes. Many of the ideas presented in this keynote address are rooted in the teachings of these gifted thinkers. Strategic tethering to a diverse group of hand-picked intellectual heroes inspires you to situate self-renewal at the very core of achieving creative excellence. Image source: Wikimedia Commons and Audra Melton (Kahneman's image), used with permission.

Dissenters may question whether poetic thought can occupy any useful place in the mind of the scientist. I say surely the act of hyphenation is capable of furnishing the discoverer with fresh and distinctive images of the world that will be utilizable in practice, what F. C. Prescott (1959) calls the "wild harvest" of the imagination, which he contrasts with the conventionally cultivated crop of analytical reason. In my skills course for scientific trainees at Purdue, I find myself advocating for a collision between the imaginative and the analytical. The students welcome this healthy collision.

Ultimately, our performance will depend on how comfortable we feel amidst the tapestry of constancy and change. If we are smugly satisfied with what we "know", our motivation for discovery is dampened. We will see world and ourselves in it as more stasis than flux. We will 
be held captive by what Wallace Stevens (1964) called our "blessed rage for order", our craving for constancy. This kind of faulty thinking places us at risk for imposing order rather than discovering - assembling a false sense of order that creates solace, rather than the impulse for re-ordering and reorientation (Ortega y Gasset, 1969). We become victims of our lack of self-awareness, ill-prepared to reach our fullest potential. We are stripped of our ability to become necessary angels.

What I'm coming to believe is that the prime goal of education should be a pursuit of self-description - a description of self-inworld. Obtaining a dead accurate accounting of the world is less important than developing the vocabulary you will use to describe yourself and your experiences (Gadamer, 1975; Rorty, 1980). This reckoning fits nicely with my evolving conception of language as gateway, poet-scientists as holding the keys to the gate, and the goal of achieving dialogic self-awareness as key to creative excellence and peak personal performance.

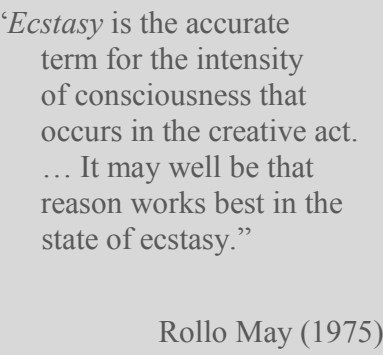
term for the intensity of consciousness that occurs in the creative act. ... It may well be that reason works best in the state of ecstasy."

Rollo May (1975)

\section{Acknowledgments}

The author thanks E. Chiang for formative discussions that shaped the keynote address and for the creative construction of figures. The author is grateful to A. Carrillo, D. Hare, and C. Suckow for their critical comments regarding the content and clarity of the manuscript.

\section{References}

Adler, M. (1940). How to read a book. New York, NY: Simon and Schuster.

Barthes, R. (1974). S/Z. (R. Miller, Trans.) New York, NY: The Noonday Press.

Bateson, G. (1979). Mind and nature: A necessary unity. London, UK: Wildwood House.

Berthoff, A. (1985). I. A. Richards. In J. Brereton (Ed.), Traditions of inquiry (pp. 50-80). Oxford, UK: Oxford University Press.

Bohm, D. (1996a). The problem and the paradox. In L. Nichol (Ed.), On dialogue (pp. 61-68). London, UK: Routledge.

Bohm, D. (1996b). The nature of collective thought. In L. Nichol (Ed.), On dialogue (pp. 48-60). London, UK: Routledge.

Bronowski, J. (1978). The origins of knowledge and imagination. New Haven, CT: Yale University Press.

Bruner, J. (1986). Actual minds, possible worlds. Cambridge, MA: Harvard University Press.

Chiang, E., Shen, S., Kengeri, S., Xu, H., Combs, G., Morris, J., ... Waters, D. J. (2009). Defining the optimal selenium dose for prostate cancer risk reduction: Insights from the U-shaped relationship between selenium status, DNA damage, and apoptosis. Dose Response, 8(3), 285-300.

Collingwood, R. G. (1924). Speculum mentis: The map of knowledge. Oxford, UK: Oxford.

Critchley, S. (2005). Things merely are: Philosophy in the poetry of Wallace Stevens. London, UK: Routledge.

Dewey, J. (1958). Experience and nature. New York, NY: Dover Publications.

Edmundson, M. (2004). Why read? New York, NY: Bloomsbury.

Emerson, R. W. (1847). Circles. In Ralph Waldo Emerson: Essays and journals (pp. 212-222). Garden City, NY: Nelson Doubleday, 1968. 
Emerson, R. W. (1893). Natural history of intellect. In The complete works of Ralph Waldo Emerson XII. Boston, MA: Houghton Mifflin, 1921.

Ferrari, M. (2002). What is excellence and how to study it? In M. Ferrari (Ed.), The pursuit of excellence through education (pp. 221-239). Mahwah, NJ: Lawrence Erlbaum Associates.

Fox, R. F. (Ed). (2000). UpDrafts: Case studies in teacher renewal. Urbana, IL: National Council of Teachers.

Gadamer, H-G. (1975). Truth and method. New York, NY: The Seabury Press.

Galileo Galilei. (1623). The assayer. In S. Drake (Ed.), Discoveries and opinions of Galileo. New York, NY: Doubleday, 1957.

Gardner, J. (1963). Self renewal: The individual and the innovative society. New York, NY: Harper \& Row.

Gelb, M. J. (1998). How to think like Leonardo da Vinci: Seven steps to genius every day. New York, NY: Dell Publishing.

Gill, T. G. (2011). When what is useful is not necessarily true: The underappreciated conceptual scheme. Informing Science: the International Journal of an Emerging Transdiscipline, 14, 1-32. Retrieved from http://www.inform.nu/Articles/Vol14/ISJv14p001-032Gill589.pdf

Iser, W (1978). The act of reading. Baltimore, MD: The Johns Hopkins University Press.

James, W. (1890). The principles of psychology. New York, NY: Henry Holt, 1927.

James, W. (1907). Pragmatism: A new name for some old ways of thinking. New York, NY: Longmans, Green, 1947.

Jones, C. T. (1968). Life is tremendous. Harrisburg, PA: Executive Books.

Johnson, W. (1946). People in quandaries. New York, NY: Harper.

Johnson, W. (1956). Your most enchanted listener. New York, NY: Harper.

Kahneman, D. (2011). Thinking, fast and slow. New York, NY: Farrar.

Maurois, A. (1968). Illusions. New York, NY: Columbia University Press.

May, R. (1975). The courage to create. New York, NY: W.W. Norton and Company.

Moffett, J. (1983). Teaching the universe of discourse. Boston, MA: Houghton Mifflin Company.

Murray, D. M. (1991). The craft of revision. Fort Worth, TX: Harcourt Brace Jovanovich.

Ortega y Gasset, J. (1969). Some lessons in metaphysics. New York, NY: W.W. Norton \& Company.

Pack, R. (1968). Wallace Stevens: An approach to his poetry and thought. New York, NY: Gordian Press.

Picasso, P. (1923, May). Picasso speaks. The Arts, pp. 315-326.

Prescott, F. C. (1959). The poetic mind. Ithaca, NY: Great Seal Books (Cornell University Press).

Quinn, M. B. (1963). Metamorphosis in Wallace Stevens. In M. Boroff (Ed.), Wallace Stevens: A collection of critical essays (pp. 54-70), Englewood Cliffs, NJ: Prentice-Hall.

Rhodes, F. H. T. (2001). The creation of the future: The role of the American University. Ithaca, NY: Cornell University Press.

Richards, I. A. (1942). How to read a page. New York, NY: Norton.

Richards, I. A. (1955). Speculative instruments. Chicago, IL: University of Chicago Press.

Richards, I. A. (1976). The secret of "feedforward". In J. P. Russo (Ed.), Complementarities: Uncollected essays (pp. 246-253). Manchester, England: Carcanet New Press. 
Ristow, M., Zarse, K., Oberbach, A., Kiöting, N., Birringer, M., Kiehntopf, M., ... Blüher, M. (2009). Antioxidants prevent health-promoting effects of physical exercise in humans. Proceedings of the National Academy of Sciences of the United States of America, 106(21), 8665-8670.

Rorty, R. (1980). Philosophy and the mirror of nature. Princeton, NJ: Princeton University Press.

Rosenblatt, L. M. (1978). The reader the text the poem: The transactional theory of the literary work. Carbondale, IL: Southern Illinois University Press.

Scholes, R. (1998). The rise and fall of English. New Haven, CT: Yale University Press.

Stevens, W. (1964). The collected poems of Wallace Stevens. New York, NY: Alfred Knopf.

Thomas, F-N., \& Turner, M. (1994). Clear and simple as the truth: Writing classic prose. Princeton, NJ: Princeton University Press.

Torrey, B. (Ed.). (1906). The writings of Henry David Thoreau: Journal. Boston, MA: Houghton Mifflin \& Company.

Waters, D. J. (2011). Aging research 2011: Exploring the pet dog paradigm. ILAR Journal, 52, 97-105.

Waters, D. J., \& Chiang, E. (2010). It's a U-shaped world: A Batesonian prescription for promoting public health. Et Cetera, 67, 218-226.

Waters, D. J., Chiang, E., \& Bostwick, D. G. (2008). The art of casting nets: Fishing for the prize of personalized cancer prevention. Nutrition and Cancer, 60(1), 1-6.

Waters, D. J., Kengeri, S., Clever, B., Booth, J., Maras, A., Schlittler, D., \& Hayek, M. G. (2009). Exploring mechanisms of sex differences in longevity: Lifetime ovary exposure and exceptional longevity in dogs. Aging Cell, 8(6), 752-755.

Waters, D. J., \& Waters, L. S. (2011). On the self-renewal of teachers. The Journal of Veterinary Medical Education, 38, 235-241.

Waters, D. J., \& Wildasin, K. (2006). Cancer clues from pet dogs. Scientific American, 295(6), 94-101.

Whicher, S. E. (1953). Freedom and fate. Philadelphia, PA: University of Pennsylvania Press.

Whitehead, A. N. (1966). Modes of thought. New York, NY: The Free Press.

Wind, Y., \& Crook C. (2006). The power of impossible thinking: Transform the business of your life and the life of your business. Upper Saddle River, NJ: Pearson Prentice Hall.

Zinsser, W. (1980). On writing well (2nd ed.). New York, NY: Harper \& Row.

Zinsser, W. (1988). Writing to learn. New York, NY: Harper \& Row.

\section{Biography}

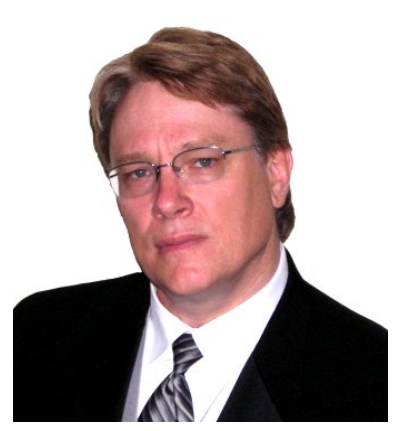

David J. Waters is Professor and Associate Director of Purdue University's Center on Aging and the Life Course, and Director of the Center for Exceptional Longevity Studies at The Gerald P. Murphy Cancer Foundation in West Lafayette, Indiana. He earned his Bachelor of Science and Doctor of Veterinary Medicine degrees from Cornell University and holds a $\mathrm{PhD}$ degree from the University of Minnesota. Trained in the comparative aspects of biogerontology and oncology, Waters utilizes cellular and animal models to better understand and promote healthy human longevity. His educational efforts focus on graduate and post-graduate training in aspects of personal performance and the biology of successful aging. 